\title{
Projektikurssilta työelämätaitoja maataloustieteiden opiskelijoille
}

\author{
Hanna-Riitta Kymäläinen ${ }^{1}$, Tuomo Kokkonen ${ }^{1}$, Hanni Muukkonen², Pirjo Mäkelä로 Mervi Seppänen ${ }^{1}$, Minna \\ Lakkala $^{3}$ \\ ${ }^{1}$ Helsingin yliopisto, Maataloustieteiden osasto, PL 28, 00014 Helsingin yliopisto, \\ hanna-riitta.kymalainen@helsinki.fi, tuomo.kokkonen@helsinki.fi, pirjo.makela@helsinki.fi, \\ mervi.seppanen@helsinki.fi \\ ${ }^{2}$ Oulun yliopisto, Kasvatustieteiden tiedekunta, PL 2000,90014 Oulun yliopisto, hanni.muukkonen@oulu.fi \\ ${ }^{3}$ Helsingin yliopisto, Kasvatustieteellinen tiedekunta, PL 9, 00014 Helsingin yliopisto, \\ minna.lakkala@helsinki.fi
}

Yliopisto-opetuksessakin korostetaan nykyään työelämärelevanssia. Substanssiosaamisen lisäksi kartutetaan mm. tiimityö-, verkostoitumis-, projektityö- ja digitaalisuusosaamista. Helsingin yliopiston maataloustieteiden kandi- ja maisteriohjelmien 5 op laajuisella projektikurssilla toteutetaan projektitöitä ulkopuolisille asiakkaille. Ensimmäisellä, vuoden 2016 kurssilla, oli 8 opiskelijaa 2 ja 3 ohjaajaa eli yliopisto-opettajaa; toisella, vuoden 2017 kurssilla, oli 15 opiskelijaa 4 tiimissä ja 6 ohjaajaa. Kunkin tiimin asiakasorganisaatiota edusti yksi tai usea henkilö. Kurssia tutkittiin ja kehitettiin suunnitteluperustaisella tutkimusmenetelmällä. Kirjallisella kyselyllä kerättiin opettajien ja opiskelijoiden arvioita kurssin onnistumisesta ja opiskelijoiden oppimista taidoista (tietokäytäntökysely), haastatteluilla opettajien ja asiakkaiden näkemyksiä kurssin toteutuksesta ja kehittämisestä. Aineisto analysoitiin kvalitatiivisin ja kvantitatiivisin menetelmin.

Tietokäytäntökyselyn mukaan opiskelijat kokivat oppineensa hyvin tietotyötaitoja, erityisesti jaetun kohteen kehittämistä, yksilöllisen ja yhteisöllisen työskentelyn yhdistämistä sekä tuotosten pitkäjänteistä kehittämistä (keskiarvot molemmilla kurssikerroilla >4, väittämä "Opin kurssin aikana...., asteikko 1 "en ollenkaan" -5 "hyvin paljon”). Avointen vastausten perusteella opiskelijat arvostivat erityisesti tiimityöskentelyä yhteisen tavoitteen saavuttamiseksi, projektityö- ja työelämätaitojen kehittymistä, mielenkiintoisia projektiaiheita sekä kanssakäymistä työelämän edustajien kanssa. Haastaviksi koettiin avoin tehtävänanto ja siihen liittyen epätietoisuus toimintatavoista, ryhmätyöskentelyn koordinointi sekä puutteet omassa osaamisessa esimerkiksi kyselytutkimuksen tekemisessä. Vuonna 2016 tiukka 11 viikon aikataulu koettiin ongelmaksi, joten v. 2017 kurssin kesto pidennettiin 16 viikkoon. Kaikki asiakkaat kokivat osallistumisen kurssille myönteisenä. He arvostivat sitä, että voivat auttaa opiskelijoita harjoittelemaan työelämäkäytäntöjä ja yliopistoa kehittämään opetusta. Yhteistyö nähtiin hyvänä tapana luoda kontakteja opiskelijoihin tulevia työpaikkoja ajatellen. Projektityö toi uutta tietoa organisaatioiden toiminnan kehittämiseksi tai täydensi ja vahvisti aiempaa tietoa. Kehittämiskohteina asiakkaat näkivät sopivan toimeksiannon määrittelyn sekä vuorovaikutuskäytäntöjen tehostamisen, kuten etäkokousten järjestämisen. Tiimien ohjaajille positiivista oli opiskelijoiden motivoitunut työskentely ja töiden valmistuminen aikataulussa. Haasteita oli mm. asiakkaiden toimeksiannon määrittelyssä, kurssin vaatimuksissa suhteessa opiskelijoiden osaamiseen ja ajankäyttöön sekä omassa ajankäytössä liittyen ohjaamiseen ja ohjausyhteistyöhön.

Työelämälähtöiset kurssit todettiin tarpeellisiksi ja palkitseviksi kaikille osapuolille. Opetusta tulee kehittää myös tutkimusperustaisesti, mikä muun muassa auttaa ottamaan huomioon niin opiskelijoiden, asiakkaiden kuin opettajienkin näkökulmia.

Avainsanat: projektikurssi, kehittäminen, tutkimus

\section{Johdanto}

Työelämärelevanssia pidetään tärkeänä myös yliopisto-opetuksessa tieteenalakohtaisten opintojen rinnalla. Esimerkiksi Helsingin yliopisto on linjannut, että sekä kandidaatin- että maisterintutkintoihin tulee sisältyä työelämäorientaatiota (HY 2017a). Geneeriset työelämätaidot liittyvät muun muassa tiimityöskentelyyn, verkostoitumiseen, projektityöskentelyyn ja digitaalisuuteen. 
Projektikurssit (HY 2015) tarjoavat opiskelijoille yhden mahdollisuuden työelämätaitojen oppimiseen ja työelämäyhteyksien kartuttamiseen. Projektityöskentelyn tavoitteena on kehittää analyyttistä ajattelua ja ongelmanratkaisukykyä sekä opittujen tietojen ja taitojen soveltamista jonkin oman alan ongelman ratkaisuun (Everwijn ym. 1993, Lee ym. 2014). Maataloustieteiden projektikurssin osaamistavoitteet on kirjattu seuraavasti: "opintojakson suoritettuaan opiskelija osaa soveltaa maataloustieteiden tietoa käytäntöön, toimia projektiryhmässä ja sen eri rooleissa, laatia projektisuunnitelman, viedä projektin läpi suunnitelman mukaisesti sekä tuottaa yhdessä ryhmän kanssa projektiraportin, joka vastaa annettua tehtävänantoa” (HY 2017c). Projektien työelämäkumppanit toimivat opiskelijoiden asiakkaina, ja projektiaiheet nousevat suoraan työelämätoimijan tarpeista. Projekteissa opiskelijat ratkovat käytännön ongelmia suunnitelmallisesti ja itse oppimisestaan vastuun ottaen (Morgan 1983, Bell 2010). Tehtävän autenttisuus sitouttaa opiskelijoita projektin toteuttamiseen ja oppimiseen (Bell 2010).

Opiskelijat hyödyntävät ja yhdistävät projekteissa niin geneerisiä taitoja kuin tieteenalan substanssitietouttakin (Everwijn ym. 1993). Projektit toteutetaan ryhmissä, ja projektioppiminen onkin yksi yhteisöllisen oppimisen muoto (Johnson ja Johnson 1999, Tsay ja Brady 2010). Nykykäsityksen mukaan asiantuntijuus ei perustu pelkästään yksilölliseen ajatteluun ja tiedolliseen osaamiseen, vaan on luonteeltaan kollektiivista (Hakkarainen ym. 2012). Asiantuntijuuden kehittyminen edellyttää osallistumista oman alan kulttuurisiin käytäntöihin ja vuorovaikutusta muiden asiantuntijoiden kanssa (Sfard 1998, Aarnio 2010). Erityisesti modernissa tietotyössä, jollaista akateemisesti koulutetut pääsääntöisesti tekevät, asiantuntijoiden työskentely suuntautuu vallitsevien käytäntöjen muuttamiseen, uusien ratkaisujen etsimiseen ja jaettujen tietokohteiden yhteisölliseen kehittämiseen (Paavola ja Hakkarainen 2005). Opiskelumenetelmät, jotka simuloivat todellisen työelämän tiedonluomisen käytäntöjä, auttavat opiskelijoita kehittämään tällaisissa tehtävissä tarvittavia tietotyön taitoja. Projektioppiminen on tästä hyvä esimerkki: se sitouttaa opiskelijat tuottamaan merkityksellisiä ja konkreettisia tuotoksia eri osapuolten yhteistyönä (Lakkala ym. 2015).

Ensimmäisiltä maataloustieteiden projektikursseilta (v. 2016 ja 2017) kerättiin tutkimusaineistoa kurssin toteutuksen arvioimiseksi ja kehittämiseksi tutkimusperustaisesti. Tutkimuksessa tarkasteltiin seuraavia kysymyksiä:

1. Miten opiskelijat ja opettajat arvioivat opiskelijoiden tietotyötaitojen oppimista kurssilla?

2. Miten opiskelijat ja asiakkaat arvioivat kokemuksiaan kurssille osallistumisesta?

3. Miten opettajat arvioivat kurssin onnistumista?

\section{Aineisto ja menetelmät}

Tutkimuksen kohteena oli kaksi ensimmäistä Helsingin yliopiston maataloustieteiden projektikurssia. Opiskelijat tekivät kurssilla tiimeinä projektityön ulkopuoliselle asiakkaalle. Asiakkaat tarjosivat kurssille etukäteen projektiaiheita, jotka tarvittaessa tarkennettiin kurssin ohjaajien eli yliopisto-opettajien ja asiakasorganisaatioiden edustajien kanssa. Opiskelijat hakivat kurssille kirjallisesti ja ilmoittavat samalla, mitkä projektiaiheet heitä kiinnostivat; lopulliset tiimit muodostettiin mahdollisuuksien mukaan näiden toiveiden pohjalta. Kunkin tiimin asiakasorganisaatiota edusti yksi tai usea henkilö. Kurssit koostuivat kolmesta kaikille osallistujille yhteisestä kurssitapaamisesta, muutamista tiimien ohjaaja- ja asiakastapaamisista sekä ryhmien itsenäisestä työskentelystä. Vuoden 2016 kurssille osallistui 8 opiskelijaa 2 tiimissä ja 3 ohjaajaa sekä edustajia kahdesta asiakasorganisaatiosta. Kurssi kesti 11 viikkoa. Vuoden 2017 kurssille osallistui 15 opiskelijaa 4 tiimissä ja 6 ohjaajaa sekä edustajia kolmesta asiakasorganisaatiosta; yhdestä organisaatiosta oli kaksi projektiaihetta. Kurssi kesti 16 viikkoa.

Opiskelijoiden ja opettajien arvioita kurssin onnistumisesta sekä opiskelijoiden oppimista taidoista arvioitiin Tietokäytäntökyselyllä (Collaborative Knowledge Practices Questionnaire, CKP, Muukkonen ym. 2017). Kysely perustuu yhteisöllisen tiedonluomisen pedagogisiin suunnitteluperiaatteisiin (Paavola ym. 2011). Opiskelijoiden kyselyssä oli kaksi avointa kysymystä kurssikokemusten arvioimiseksi (Mikä oli positiivista tai vaikuttavaa? Mikä oli haastavaa tai häiritsevää?) sekä 27 väittämää kurssilla opittujen tietotyön taitojen arvioimiseksi (esim. Opin kurssin kuluessa ottamaan vastuuta yhteisestä ryhmätyöstä tai ...toimimaan yhteistyössä eri alojen edustajien kanssa). Opettajien kyselyssä kysyttiin avoimilla kysymyksillä kurssin pedagogisista käytännöistä sekä kurssin onnistumisesta (Mikä onnistui hyvin? Mikä ei onnistunut hyvin?); lisäksi opettajat arvioivat em. väittämillä, kuinka hyvin opiskelijat heidän mielestään oppivat tietotyön taitoja. Asiakasorgani- 
saatioiden edustajat haastateltiin puolistrukturoidulla haastattelulla yksittäin tai ryhmänä, jos samasta organisaatiosta osallistui useampi henkilö. Haastattelu käsitteli projektityöskentelyn onnistumista ja kurssin toteutuksen piirteitä asiakkaan näkökulmasta.

Opiskelijoiden avoimet vastaukset sekä asiakashaastattelut analysoitiin temaattisella sisällönanalyysilla (Braun ja Clarke 2006). Aluksi aineistosta valittiin koodattavaksi tekstipätkät, joissa vastaajat mainitsivat yksittäisen asian, joka liittyi kurssin toteutukseen tai osallistumiskokemukseen. Näistä maininnoista analysoitiin erikseen positiivisina/vaikuttavina ja haastavina/häiritsevinä koetut asiat. Tarkemmassa analyysissa sovellettiin aiemmassa tutkimuksessa (Lakkala ym. 2015) kehitettyjä analyysiluokkia: kurssi kokonaisuutena (yleinen arvio kurssista, aikataulu ym.), tehtävät (tehtävien piirteet, kokemus tehtävistä), ohjaus (ohjeiden ja ohjauksen laatu ja riittävyys), yhteistyö (ryhmätyöskentely, vuorovaikutus osanottajien kesken) sekä tulokset (oppiminen, hyödyt ja tuotokset). Opettajien avoimista kyselyvastauksista koskien kurssin onnistumista sekä asiakkaiden ehdottamista parannuksista kurssin toteutukseen tehtiin kuvaileva yhteenveto.

\section{Tulokset}

Kyselyväittämien perusteella opiskelijat kokivat oppineensa kumpanakin toteutusvuonna hyvin tietotyötaitoja (Kuva 1). Erityisesti koettiin opitun jaetun kohteen kehittämistä, yksilöllisen ja yhteisöllisen työskentelyn yhdistämistä sekä tuotosten pitkäjänteistä kehittämistä. Ensimmäisenä vuonna, jolloin otettiin käyttöön uusi oppimisympäristö (OneDrive Moodlen lisänä), teknologian hyödyntäminen yhteistyössä nousi esiin, mutta toisena vuonna sen oppiminen jäi matalammaksi. Matalimmat keskiarvot olivat monialaisen yhteistyön oppimisen mittarissa, mikä oli odotettua, koska opiskelijoilla oli saman tieteenalan tausta. Kumpanakin vuotena opettajat arvioivat taitojen kehittyneen enemmän kuin opiskelijat, mutta korostivat samoja taitoja. Opettajien arviot olivat kokonaisuutena alhaisemmat vuonna 2017 kuin vuonna 2016.

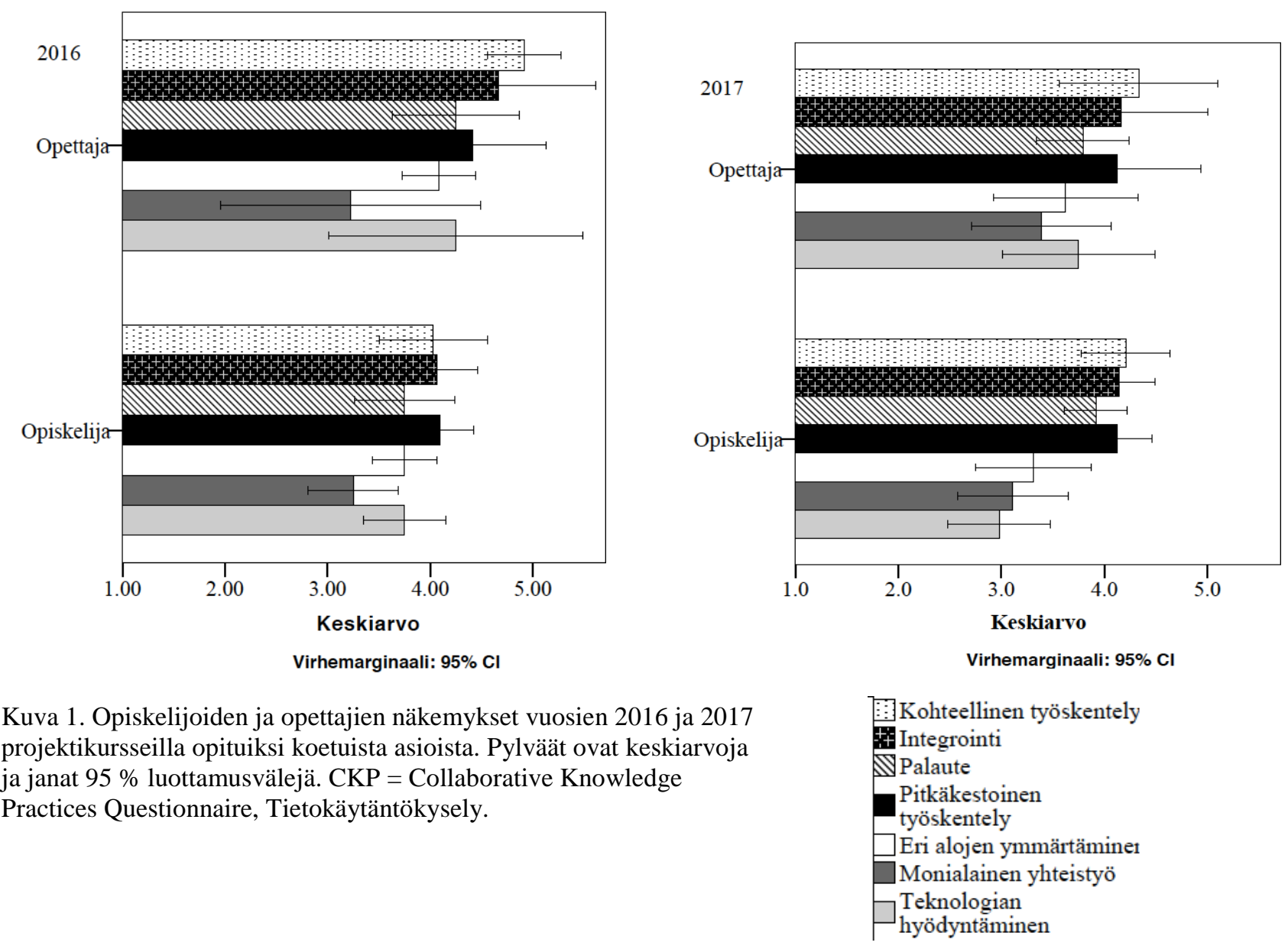


Kurssikokemuksia arvioitiin laadullisen aineiston perusteella. Kahden vuoden kurssien opiskelijoiden avoimista vastauksista eroteltiin 54 myönteisiä ja 28 kielteisiä näkemyksiä sisältänyttä mainintaa (kuva 2).

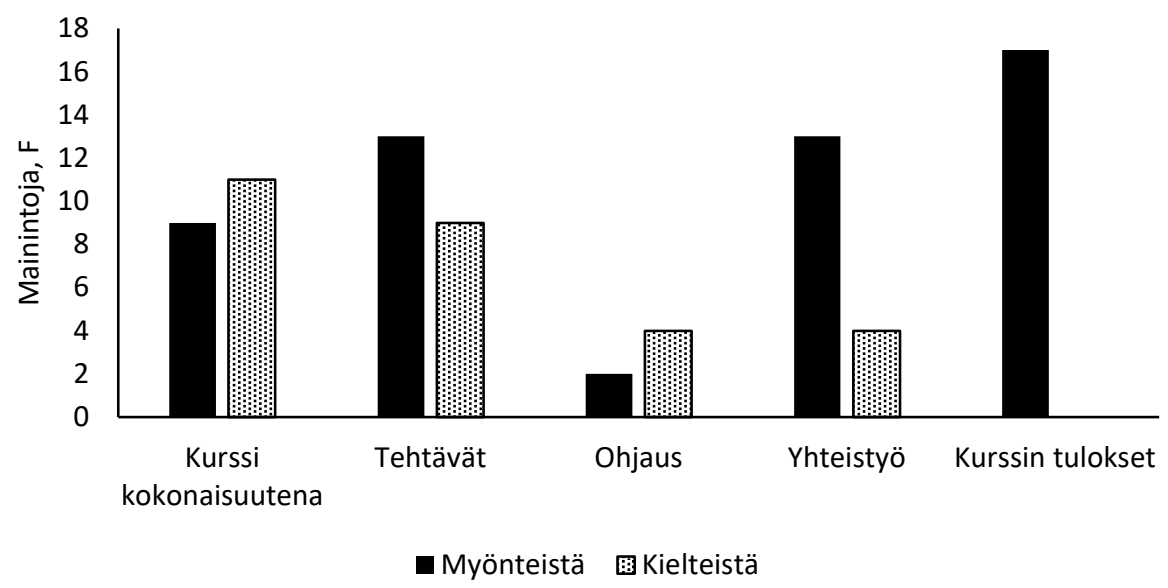

Kuva 2. Opiskelijoiden arviot kurssin kokemuksista. Pylväät kuvaavat kuhunkin ryhmään luokitellun maininnan vastausten määrää avoimissa vastauksissa.

Selkeästi myönteisimmäksi seikaksi opiskelijoiden vastausten perusteella koettiin kurssin tulokset; erityisesti mainittiin projektityötaitojen oppiminen, verkostoituminen ja yleensä uusien asioiden oppiminen. Tehtävien osalta myönteisinä seikkoina mainittiin muun muassa projektityön toteuttaminen, kiinnostava projektityön aihe sekä opiskelijoille annettu vastuu (esim. "Haasteellinen projekti oli myös positiivinen kokemus normaaliin opiskeluun verrattuna”). Tehtäviä koskevat kielteiset maininnat liittyivät projektityön tekemisen haasteisiin, kuten työn aloittamiseen, suunnitelmien muuttamiseen tai tulosten käsittelyyn. Myös kurssilla tehty yhteistyö sekä opiskelijaryhmän kesken että asiakkaan kanssa koettiin pääasiassa myönteisesti. Kielteiset opiskelijamaininnat yhteistyöstä koskivat työmäärän epätasaista jakautumista ryhmässä, aikataulujen yhteensovittamista ja puutteita kommunikaatiossa, mutta näitä mainintoja oli yhteensä vain neljä. Muutamat ohjaukseen liittyvät kommentit koskivat toisaalta hyväksi koettua palautetta opettajilta ja toisaalta liian niukaksi koettua ohjausta. Kurssi kokonaisuutena sai opiskelijoilta jonkin verran enemmän kielteisiä kuin myönteisiä mainintoja, mutta lähes kaikki kielteiset maininnat liittyivät ensimmäisen vuoden (2016) kurssin aikatauluun (esim. "Aikaresurssit ja työn laajuus suhteutettuna toisiinsa -> liian kiire").

Asiakashaastatteluista analyysiin valittiin 92 mainintaa, jotka sisälsivät arviointia kurssista ja siihen osallistumisesta. Näistä 66 sisälsi myönteisiä ja 26 kielteisiä näkemyksiä (Kuva 3).

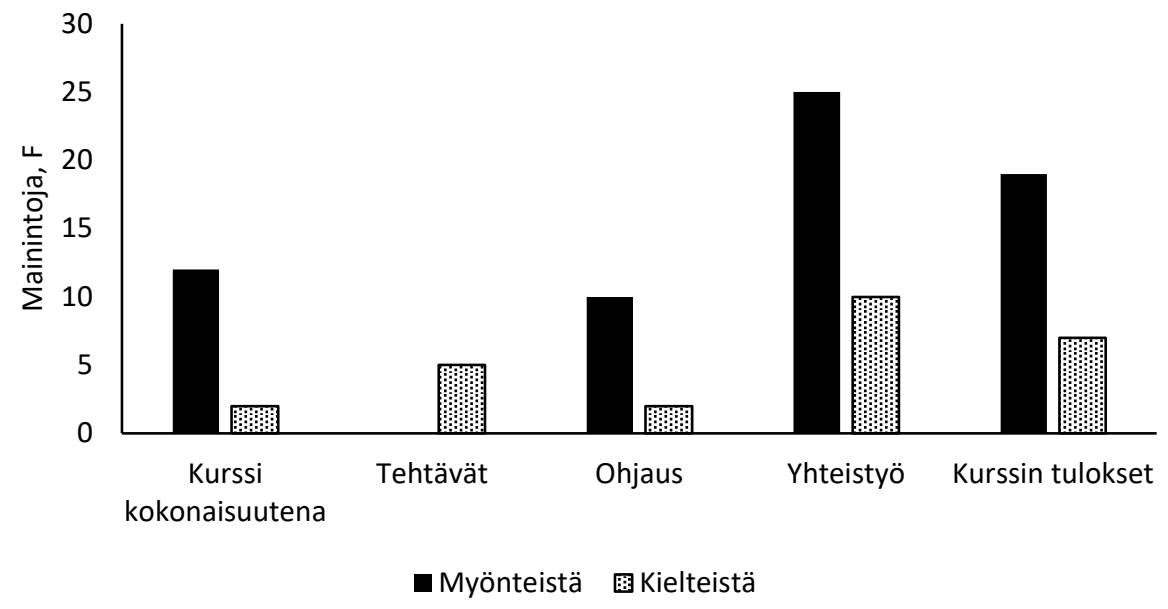

Kuva 3. Asiakkaiden arviot kurssien kokemuksista. Pylväät kuvaavat kuhunkin ryhmään luokitellun maininnan vastausten määrää avoimissa vastauksissa. 
Asiakkaat mainitsivat haastatteluissa useasti myönteisessä mielessä erityisesti opiskelijoiden kanssa tehdyn yhteistyön ja sen sujuvuuden (kommunikointi, keskustelut, työnjako ryhmässä, aikataulun ja pelisääntöjen noudattaminen); esimerkiksi: “Ja jotenkin mun mielestä se oli, niin kun tää yhteydenpito ja mitä tossa sähköpostin kautta käytiin palautteita ja muuta läpi, niin se oli tosi toimivaa, että sieltä nopeesti vastattiin ja kommentoitiin ja otettiin. Ylipäänsä kommunikaatio pelas hyvin.” Kriittiset maininnat yhteistyöstä koskivat tarvetta selkeyttää omaa roolia asiakkaana sekä joitakin yksittäisiä oman projektiryhmän yhteydenpidossa esiintyneitä puutteita. Kurssin tulosten osalta asiakkaiden myönteiset kommentit koskivat kolmea asiaa: yleensäkin projektityön onnistunutta suorittamista, projektin tuotoksena syntynyttä raporttia ja sen tuloksia sekä opiskelijoilta saatuja uusia ajatuksia ja ideoita. Tuloksiin liittyvät kriittiset kommentit koskivat kolmen projektin aineistonkeruun menetelmissä (kyselyt, haastattelut) esiin tulleita ongelmia sekä kahden projektin osalta hieman odotuksia vaatimattomampaa lopputyön sisältöä. Ohjauksen osalta asiakkaat olivat pääosin tyytyväisiä omaan panokseensa opiskelijoiden ohjaamisessa; pari kriittistä kommenttia liittyi käytettävissä olleisiin resursseihin. Opettajien ohjauskäytännöistä asiakkailla ei ollut selvää käsitystä. Tehtäviin liittyvät kriittiset kommentit koskivat kaikki projektiaiheen määrittelyn ja rajaamisen vaikeutta tällaiselle kurssille sopivaksi. Kuten opiskelijoilla, kurssin kokonaisuutta koskevat kielteiset kommentit liittyivät ensimmäisen kurssin aikataulun tiukkuuteen, muuten kurssin toteutus ja sille osallistuminen asiakkaana saivat hyvin myönteisiä mainintoja (esim. "No, siis ihan se kokonaisuus mun mielestä onnistu hyvin ja se oli meille helppo jotenkin osallistua.”)

Asiakkaat esittivät haastatteluissa vain muutaman kurssin kehittämistä koskevan ehdotuksen. Kolmen asiakasorganisaation edustajat ehdottivat, että opiskelijoiden ja asiakkaan välisessä yhteistyössä voisi enemmän hyödyntää modernia digitaalista teknologiaa, esimerkiksi järjestämällä virtuaalipalavereja. Samoin kolmelta asiakkaalta tuli ehdotus, että opiskelijoiden ja asiakkaan kesken voisi olla enemmän vuorovaikutusta erityisesti prosessin alussa. Kolme asiakasta pohti myös sitä, että kurssin monitieteisyys ja heterogeenisempi opiskelijajoukko olisi heidän kannaltaan mielenkiintoista ja hyödyllistä. Yksi asiakas toivoi enemmän tapaamisia projektiryhmän kanssa ja yksi ehdotti projektiaiheiden tarkempaa miettimistä etukäteen.

Opettajat eli tiimien ohjaajat kokivat positiivisena opiskelijoiden motivoituneen työskentelyn, yhteistyön onnistumisen asiakkaiden kanssa, projektien valmistumisen aikataulussa sekä asiakkaiden tyytyväisyyden. Lisäksi opettajien kommenteissa korostui opettajien keskinäisen yhteistyön ja vastuunjaon merkitys kurssin onnistuneelle läpiviennille. Haasteita oli opettajien mielestä muun muassa asiakkaiden toimeksiannon määrittelyssä sekä kurssille määritellyissä vaatimuksissa ottaen huomioon opiskelijoiden todellisen osaamisen ja ajankäytön. Lisäksi opettajat kommentoivat, että oma rooli opiskelijatiimin ohjaajana sekä työnjako muiden opettajien kanssa oli epäselvä. Opettajien parannusehdotuksia olivat esimerkiksi kurssin osaamistavoitteiden tarkistaminen, asiakastoimeksiantojen parempi määrittely, projektityön ideointi- ja suunnitteluvaiheen parempi tukeminen, lähitapaamisten sisältöjen ja toimintatapojen kehittäminen, opiskelijoiden tutkimusmenetelmätaitojen vahvistaminen sekä opettajien keskinäisen vastuunjaon selventäminen. Lisäksi ensimmäisen (vuoden 2016) kurssin osalta ehdotettiin kurssin pidentämistä, mikä toteutettiinkin seuraavalla kerralla. Vastauksissa mainittiin myös tarve löytää keinoja houkutella tuleville projektikursseille enemmän opiskelijoita.

Kurssin osaamistavoitteet oli kirjattu nyt tutkituilla kahdella kurssilla varsin konkreettiseen muotoon (“...osaa soveltaa maataloustieteiden tietoa käytäntöön, toimia projektiryhmässä ja sen eri rooleissa; laatia projektisuunnitelman; viedä projektin läpi suunnitelman mukaisesti; tuottaa yhdessä ryhmän kanssa projektiraportin, joka vastaa annettua tehtävänantoa). Jatkossa voidaan opettajilta saatuun palautteeseenkin viitaten miettiä, olisiko osaamistavoitteita syytä tarkentaa esimerkiksi seuraavankaltaisilla maininnoilla: "osaa toimia asiantuntijamaisilla tavoilla tiedon käsittelemisessä, arvioinnissa ja tuottamisessa”, “osaa toimia yhteistyössä asiakkaiden kanssa”, “osaa työskennellä tiimissä”, “osaa suunnitella ja johtaa projektia” tai “osaa arvioida ja antaa palautetta tiimin toiminnasta”.

\section{Tulosten tarkastelu}

Opettajat arvioivat väittämävastauksissa opitun määrän hieman suuremmaksi kuin opiskelijat. Tämä oli yhteneväinen havainto Muukkosen ym. (2017) tutkimuksen kanssa. Opiskelijoiden avoimien vastausten perusteella todetut kokemukset olivat osin samansuuntaisia kuin Lakkalan ym. (2015) tutkimuksessa, jossa samantyyppisen, asiakkaalle tehtävään projektityöhön perustuvan kurssin tulokset (taitojen oppiminen, projektin tuotos) saivat paljon myönteisiä mainintoja, kun taas haasteena mainittiin aikataulu. Itse projektitehtävän opiskelijat kokivat molempien tutkimusten perusteella sekä hyvin antoisaksi että haastavaksi. Vuonna 2016 tiukaksi koetun 11 viikon aikataulun vuoksi kurssin kesto pidennettiin seuraavana vuonna 16 viikkoon. Asiakkaiden mainitsema kurssin 
alun hämmennys tuli esille myös vuoden 2016 opiskelijoiden näkemyksissä (Mäkelä ym. 2017), ja tapaamiset asiakkaan kanssa ovatkin keskeistä projektin onnistuneelle etenemiselle.

Vaikka projektikurssit osoittautuivat opiskelijoille pääosin haastaviksi, haastavuus kääntyi tutkimuksen tulosten perusteella lopulta ensisijaisesti hyväksi oppimiskokemukseksi. Tämä edellyttää kuitenkin panostusta kurssin organisointiin ja opiskelijoiden ohjaukseen, joita oli nyt raportoitavissa kursseissa mietitty perusteellisesti, mutta joita tullaan saadun palautteen perusteella kehittämään edelleen. Muukkosen ym. (2013) tutkimuksessa todettiin, että opiskelijat kokivat varsinkin projektikurssin alkuvaiheen erittäin haastavaksi, kun perinteisestä opettajajohtoisesta opetustavasta siirryttiin itseohjautuviin tiimeihin. Haastavuuden kokemus saattoi siis nyt tutkituilla kursseillakin liittyä opiskelijoille varsin harvinaiseen kurssityyppiin tai opetustapaan. Tapaaminen asiakkaan kanssa auttoi tiimejä etenemään. Mäkelän ym. (2017) mukaan opiskelijat kokivat, että maataloustieteiden aiemmat opinnot loivat perusvalmiuksia projekteissa toteutettujen kyselytutkimusten toteuttamiseen ja rohkeutta mielipiteiden esittämiseen, kun esimerkiksi alan käsitteet olivat tuttuja.

Osa ohjaajista oli samoja vuosina 2016 ja 2017. Opettajat arvioivat opiskelijoiden oppimat taidot vuonna 2016 yleisesti ottaen suuremmiksi kuin vuonna 2017. Tämä johtui ainakin osin siitä, että kyselyyn vastaaja "oppi” edellisen vuoden tuloksista ja sopeutti vuoden 2017 vastauksiaan lähemmäs opiskelijoiden aiemman vuoden vastausten tasoa.

Projektikurssit edellyttävät yliopisto-opettajilta pedagogisten käytäntöjen kehittämisen lisäksi uusien toimintatapojen luomista myös työelämäyhteistyöhön ja yhteisopettajuuteen - käytännöt eivät kehity kerralla, vaan tarvitaan kiinnostuneita opettajia, useita kokeilukertoja ja kokemusten yhteisöllistä reflektointia. Tämä toteutui jo nyt tutkittujen kahden kurssin osalta. Erityisesti kurssien suunnitteluun ja myös ennakkovalmisteluihin oli käytetty runsaasti aikaa, ja jälkimmäistä kurssia kehitettiin ensimmäisestä kurssista saatujen kokemusten ja tutkimustulosten perusteella. Maataloustieteiden projektikurssit ovat jatkumo toiselle työelämätaitojen kurssille (HY 2017b), jota varten oli laadittu myös oppimateriaali (Kymäläinen ym. 2016). Kursseja on kehitetty vuorovaikutuksessa myös muiden Helsingin yliopiston toimijoiden kanssa (HY 2015). Kaikille nyt tutkittujen kurssien projekteille onnistuttiin saamaan sitoutuneet ohjaajat, mikä oli merkittävää projektien ja kurssin onnistumisen kannalta. Vaihtuvien projektiaiheiden ja projektien ohjaajien hankkiminen edellyttää opettajilta avoimuutta uusille toimintakäytännöille, halukkuutta yhteistyöhön sidosryhmien kanssa sekä ketterää toimintaa.

\section{Johtopäätökset}

Opiskelijat raportoivat oppineensa juuri niitä taitoja, joita kurssille oli määritelty osaamistavoitteissa. Projektikurssin tutkimustulokset osoittivat, että yhteistyötä yliopisto-opetuksen ja työelämän edustajien kanssa on mahdollista toteuttaa niin, että kaikki osapuolet ovat tyytyväisiä. Projektikurssin haastavuus voi kääntyä myönteiseksi oppimiskokemukseksi, kunhan kurssi on toteutettu hyvin. Nyt tutkittujen kurssien suunnitteluun ja valmisteluihin oli panostettu merkittävästi. Kaikki osapuolet pitivät työelämälähtöisiä projektikursseja opettavaisina, tarpeellisina ja palkitsevina. Osallistujilta kerätty tutkimusaineisto toi esiin hyödyllistä tietoa kurssikäytäntöjen kehittämiseksi. Opetusta tulee jatkossakin kehittää myös tutkimuksen keinoin.

\section{Kirjallisuus}

Aarnio, H. 2010. Oppimisen ohjaaminen. Teoksessa Helakorpi, S., Aarnio, H. \& Majuri, M. (toim.) Ammattipedagogiikkaa uuteen oppimiskulttuuriin. HAMK Ammatillinen opettajakorkeakoulu. s. 155-178.

Bell, S. 2010. Project-based learning for the 21st century: skills for the future. The Clearing House: A Journal of Educational Strategies, Issues and Ideas 83: 39-43.

Braun, V. \& Clarke, V. 2006. Using thematic analysis in psychology. Qualitative Research in Psychology 3: 77-101. Everwijn, S.E.M., Bomers, G.B.J. \& Knubbem, J.A. 1993. Ability- or competence-based education: bridging the gap between knowledge acquisition and ability to apply. Higher Education 25: 425-438.

Hakkarainen, K., Lallimo, J. \& Toikka, S. 2012. Kollektiivinen asiantuntijuus ja jaetut tietokäytännöt. Aikuiskasvatus 32: 246-256.

HY 2015. Tieteestä toimintaa -projektikurssit. https://www.helsinki.fi/fi/tieteesta-toimintaa-projektikurssit. Viitattu 8.12.2017.

HY 2017a. Helsingin yliopiston tutkintoja ja opintoja koskevat linjaukset. HY/495/00.00.06.00/2017. Liite 19.6.2017.

HY 2017b. Projektinhallinta- ja työelämätaidot. https://courses.helsinki.fi/fi/maat-004. Viitattu 3.1.2018.

HY 2017c. Projektityö. https://courses.helsinki.fi/fi/maat-005. Viitattu 8.12.2017.

Johnson, D.W. \& Johnson, R.T. 1999. Making cooperative learning work. Theory into Practice 38: 67-73. 
Kymäläinen, H.-R., Lakkala, M.H., Kamppari, K. \& Carver, E. 2016. Opas projektityöskentelyyn. Tieteestä toimintaa -verkosto, Helsingin yliopisto. 78 s. http://hdl.handle.net/10138/160099

Lakkala, M., Toom, A., Ilomäki, L. \& Mukkonen, H. 2015. Re-designing university courses to support collaborative knowledge creation practices. Australasian Journal of Educational Technology 31: 521-536.

Lee, J.S., Blackwell, S., Drake, J. \& Moran, K. A. 2014. Taking a leap of faith: redefining teaching and learning in higher education through project-based learning. Interdisciplinary Journal of Problem-Based Learning 8 https://doi.org/10.7771/1541-5015.1426

Morgan, A. 1983. Theoretical aspects of project-based learning in higher education. British Journal of Educational Technology 14: 66-78.

Muukkonen, H., Kosonen, K., Marttiin, P., Vesikivi, P., Kaistinen, J. \& Nyman, G. 2013. Pedagogical design for knowledge creation in customer projects. Knowledge Management \& E-Learning 5: 278-297.

Muukkonen, H., Lakkala, M., Toom, A. \& Ilomäki, L. 2017. Assessment of competences in knowledge work and object-bound collaboration during higher education courses. In E. Kyndt, E., V. Donch, K. Trigwell \& S. LindblomYlänne (eds.) Higher education transitions: Theory and research. EARLI book series "New Perspectives on Learning and Instruction". Routledge - Taylor \& Francis Group. p. 288-305.

Mäkelä, P., Kymäläinen, H.-R., Lakkala, M. \& Muukkonen, H. 2017. Aiempien maataloustieteiden opintojen merkitys projektityön toteuttamisessa. Yliopistopedagogiikka 24: 43-46.

Paavola, S. \& Hakkarainen, K. 2005. The knowledge creation metaphor - An emergent epistemological approach to learning. Science \& Education 14: 535-557.

Paavola, S., Lakkala, M., Muukkonen, H., Kosonen, K. \& Karlgren, K. 2011. The roles and uses of design principles for developing the trialogical approach on learning. Research in Learning Technology 19: 233-246.

Sfard, A. 1998. On two metaphors for learning and the dangers of choosing just one. Educational Researcher 27: 4-13. Tsay, M. \& Brady, M. 2010. A case study of cooperative learning and communication pedagogy: does working in teams make a difference? Journal of the Scholarship of Teaching and Learning 10: 78-89. 